\title{
THERASENSE V. BECTON DICKINSON: A FIRST IMPRESSION
}

\author{
Jason Rantanen ${ }^{*} \&$ Lee Petherbridge, Ph.D. ${ }^{\dagger}$
}

14 YALE J.L. \& TECH. 226 (2012)

\begin{abstract}
This Article provides the first major analysis of the very recent en banc decision of the United States Court of Appeals for the Federal Circuit in the now famous Therasense v. Becton Dickinson. The doctrinal issue central to the case is inequitable conduct, a judicially created doctrine developed to punish patent applicants who behave inappropriately during patent prosecution, the ex parte process of patent creation. The core thesis of this Article is that Therasense could have a much more significant, complex, and nuanced impact on the legal infrastructure of American innovation than the opinion for the court appears to appreciate. In view of these complexities, the court may be too sanguine in its expectations for the instrumental effect of its decision, a decision that has the potential to erode some of the core pillars upon which the legal infrastructure of American innovation is built.
\end{abstract}

* Associate Professor, University of Iowa College of Law. In the interest of full disclosure, it should be noted that prior to his academic career, the author represented Abbott Laboratories in Therasense v. Becton Dickinson. The author further notes that the purpose of this Article is to discuss the broad public policy implications of the Federal Circuit's en banc opinion, and nothing in this Article should be construed as constituting a view on whether or not a determination of inequitable conduct is appropriate in this particular case. Comments on this Article are welcome and may be sent to jason-rantanen@uiowa.edu.

${ }^{\dagger}$ Professor of Law, Loyola Law School, Los Angeles. We are extremely grateful to the very many patent practitioners who corresponded with us in connection with the initial draft of this Article. The character of the comments we received was overwhelmingly thoughtful and informed. We have closely examined the comments and distilled from them the issues most commonly voiced, and in some instances, vigorously pressed. We address those comments in, primarily, Part II.D, entitled Implications for Patent Practitioners. We are also grateful to Kimberly West-Faulcon, Ali Mojibi, David L. Schwartz, Mark Lemley, and Herbert Hovenkamp for their helpful comments concerning this study and earlier drafts. 


\section{TABLE OF CONTENTS}

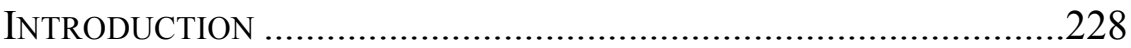

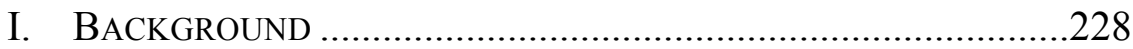

A. The Case ............................................................ 233

B. The En Banc Opinion ............................................... 236

II. LAW AND PoliCy ISSUES RAISED By THERASENSE ..................237

A. A Patent Handout .................................................... 238

B. Implications for Patent Quality............................... 241

C. Implications for Patent Litigation ............................. 245

D. Implications for Patent Practitioners ....................... 250

1. Will Therasense Really Change Case Outcomes? .....251

2. Will Therasense Solve the Problem of Applicant

Overdisclosure? ...................................................254

E. What Does It All Mean? .......................................... 260

III. A GLIMPSE OF THE NEW FEDERAL CiRCUIT? .......................262

1. An Ex Post, not an Ex Ante Patent System................262

2. A More Political Federal Circuit?............................263

3. A Pro-Patentee Federal Circuit?.............................264

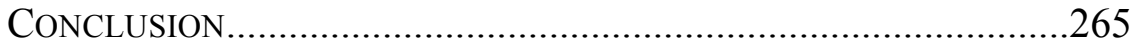




\section{INTRODUCTION}

The purpose of this Article is to provide an early analysis of some of the most substantial law and policy concerns raised by the very recent en banc decision of the United States Court of Appeals for the Federal Circuit in the now-famous Therasense $v$. Becton Dickinson case. ${ }^{1}$ The doctrinal issue central to the case is inequitable conduct, a judicially created doctrine developed to punish patent applicants who behave inappropriately during patent prosecution, the ex parte process of patent creation.

The core thesis of this Article is that Therasense could have a much more significant, complex, and nuanced impact on the legal infrastructure of American innovation than the opinion for the court appears to appreciate. In view of these complexities, the court may be too sanguine in its expectations for the instrumental effect of its decision. More specifically, there are few reasons to be confident that the new doctrinal regime imposed by Therasense is well crafted to remedy any putative problems encouraged by the old law. Moreover, there is much reason to believe that the new doctrine could aggravate existing problems with the patent system and establish new ones. In sum, this is a decision that holds the potential to erode the legal infrastructure of American innovation.

To enhance understanding of the concerns developed in the analysis, the first Part of this Article provides a background that explains the innovation context and history of the case and describes the relevant legal dispute. The second Part of this Article is devoted to an early analysis of substantial innovation law and policy concerns raised by the decision of the court. We finish with a brief third Part, in which we consider what the Therasense case might reveal about the "new" Federal Circuit.

\section{BACKGROUND}

United States Patent No. 5,820,551, the patent at the heart of Therasense v. Becton Dickinson, had its origins in a United Kingdom laboratory in the early $1980 \mathrm{s.}^{2}$ There, a team of pioneering scientists came together to develop a groundbreaking way for diabetes patients to monitor their blood glucose levels-a

\footnotetext{
${ }^{1} 649$ F.3d 1276 (Fed. Cir. 2011).

${ }^{2}$ U.S. Patent No. 5,820,551 (filed June 6, 1995). Background information comes from Therasense, 649 F.3d 1276; Therasense, Inc. v. Becton Dickinson \& Co., 593 F.3d 1289 (Fed. Cir. 2010) (rehearing en banc granted, opinion vacated); and Therasense, Inc. v. Becton Dickinson \& Co., 565 F. Supp. 2d 1088 (N.D. Cal. 2008).
} 
crucial advance in the treatment of diabetes, a disease whose growth rate over the past few decades has reached epidemic proportions. To give a sense of the magnitude of the epidemic, government statistics show that in 1980, 5.6 million Americans were diagnosed with the difficult-to-manage and potentially debilitating disease; ${ }^{3}$ by 2010 , that number had climbed to a startling 18.8 million Americans (with another 7.0 million believed to be undiagnosed). ${ }^{4}$

The device developed by these scientists was simple and elegant. It began with the creation of an improved sensor coated with biochemical compounds that produced a tiny flow of electricity in the presence of glucose, an invention that led to patent number 4,545,382 in the United States and patent number EP 0078636 in Europe. The scientists next placed the new sensor on a test strip that could be inserted into a meter to produce a digital readout of the blood glucose level and then thrown out. ${ }^{5}$ This innovation made it possible for anyone to test their blood glucose at any time, leading to a revolution in diabetes patient care. $^{6}$

As with the sensor invention, the scientists sought a patent for the disposable test strip. However, unlike the patent application directed to the glucose sensor - the one that gave rise to the '382 patent - the patent application directed to the disposable test strip was repeatedly rejected by the patent office. ${ }^{7}$ The rejection of the scientists' claims was based, perhaps ironically, on the earlier invention of the ' 382 patent. ${ }^{8}$ Medisense, the assignee of the patent application and the company commercializing the test strips, repeatedly sought to overcome the rejections, amending the proposed claims and submitting declarations to distinguish the prior art or tout the commercial success of its disposable test strips. ${ }^{9}$ For fourteen years, these attempts failed to sway the

3 Ctr. for Disease Control \& Prevention, Number (in Millions) of Civilian Noninstitutionalized Persons with Diagnosed Diabetes, 1980-2010, U.S. DEP'T HEALTH \& HuM. SERVICES, http://www.cdc.gov/diabetes/statistics/prev/national/figpersons.htm (last updated Dec. 9, 2011).

${ }^{4}$ Ctr. for Disease Control \& Prevention, National Diabetes Fact Sheet 2011, U.S. DEP'T HeAlTh \& Hum. SERVICES 1 (2011), http://www.cdc.gov/diabetes/pubs/pdf/ndfs_2011.pdf. The CDC estimates that $35 \%$ of U.S. adults aged 20 years or older have prediabetes, a condition associated with a high risk of developing diabetes.

${ }^{5}$ Therasense, 565 F. Supp. $2 \mathrm{~d}$ at 1093.

${ }^{6}$ See Adam Heller \& Ben Feldman, Electrochemical Glucose Sensors and Their Applications in Diabetes Management, 2008 CHEM. REV. 2482, 2492 (2008).

${ }^{7}$ Therasense, 565 F.Supp. 2d at 1093.

${ }^{8} I d$.

${ }^{9} I d$. 
examiner. $^{10}$

All these failures turned into apparent success, however, when in 1996 Abbott Laboratories acquired Medisense and assigned one of its in-house patent attorneys, Lawrence Pope, to take over the prosecution of the disposable test strip patent application. Mr. Pope was a veteran patent attorney with years of experience representing patent applicants before the patent office. ${ }^{11}$ He and a Medisense scientist, Dr. Gordon Sanghera, brainstormed various patentability arguments, striking upon a potential point of novelty in the disposable test strip application that had been previously overlooked: the application described a disposable test strip with a glucose sensor for use without any membrane protecting the sensor from the many constituents of whole blood, while the older, sensor-only technology used a protective membrane to separate the blood from the sensor. ${ }^{12}$ Emphasizing the fact that the disposable test strip invention did not require a protective membrane might be sufficient to overcome the patent office's rejections and render the claims patentable.

The difficulty Mr. Pope and Dr. Sanghera faced, however, was that a portion of the '382 patent discussed membraneless sensors. It read, "Optionally, but preferably when being used on live blood, a protective membrane surrounds both the enzyme and the mediator layers, permeable to water and glucose molecules." 13 Because this passage had the potential to defeat the patentability of the disposable test strip application, Pope argued that skilled artisans in 1983 would have believed that a membrane was essential even in the face of the ' 382 disclosure - in other words, that skilled artisans would not have taken the quoted sentence literally. ${ }^{14}$

The problematic passage was discussed at a meeting between Pope and the patent examiner, during which the examiner agreed that rejections based on the '382 patent could be overcome if an affidavit or other evidentiary showing was made that at the time of the invention, a membrane was considered essential. ${ }^{15}$ This evidence was provided in the form of a declaration by Dr. Sanghera, in which he explained that:

[B]ased on his historical knowledge he is confident that on the filing date of the earliest application leading to the present application on June 6,1983

\footnotetext{
${ }^{10} I d$.

${ }^{11} I d$.

${ }^{12}$ Id. at 1093-94.

${ }^{13}$ U.S. Patent No. 4,545,382 (filed Oct. 22, 1982).

${ }^{14}$ Therasense, 565 F. Supp. $2 \mathrm{~d}$ at 1094.

${ }^{15} \mathrm{Id}$.
} 
and for a considerable time thereafter one skilled in the art would have felt that an active electrode comprising an enzyme and a mediator would require a protective membrane if it were to be used with a whole blood sample. Therefore he is sure that one skilled in the art would not read lines 63 to 65 of column 4 of U.S. Patent No. 4,545,382 to teach that the use of a protective membrane with a whole blood sample is optionally [sic] or merely preferred. $^{16}$

Along with the declaration, Pope submitted remarks based on Sanghera's representation that argued that a person of ordinary skill in the art would have understood the passage in the '382 patent to be mere "patent phraseology," as opposed to a technical teaching. ${ }^{17}$ Shortly thereafter, the '551 patent was allowed, and Abbott subsequently asserted it against several manufacturers and distributors of electrochemical diabetes test strips, including Becton Dickinson ("BD") and Bayer. ${ }^{18}$

During the infringement litigation, BD and Bayer discovered that before Abbott acquired Medisense, the '636 patent (the European counterpart to the '382 patent, with an essentially identical written body) was the subject of an inter partes opposition proceeding at the European Patent Office that challenged the patent's validity. Important to the opposition to the '636 patent in Europe was a document known as the "D1" reference. In the proceeding, Medisense argued that D1 could be distinguished on two grounds: first, that the '636 invention used a different type of chemical (a ferrocene mediator) than was used in D1, and second, that D1 required a semi-permeable membrane to control the flow of glucose while the '636 invention did not. ${ }^{19}$ In arguing the latter ground, Medisense specifically referenced the "[o]ptionally, but preferably" passage shared by the ' 382 and ' 636 patents that would later become central to Pope and Sanghera's strategy to secure the '551 patent. Medisense's European appeal brief argued that:

10. The above object is solved by a glucose sensor as defined in claim 1 of the patent in suit ['382/'636]. Apart from the important feature of utilizing a ferrocene or ferrocene derivative as mediator, another important difference over D1 resides in that the claimed glucose sensor-contrary

\footnotetext{
${ }^{16} \mathrm{Id}$.

${ }^{17} I d$. at 1093.

${ }^{18} I d$. at 1091.

${ }^{19} \mathrm{Id}$. at 1108 .
} 
to that of D1 which requires a membrane-does not have and must not have a semipermeable membrane within the meaning of D1. Contrary to the semipermeable membrane of $\mathrm{D} 1$, the protective membrane optionally utilized with the glucose sensor of the patent [in] suit is not controlling the permeability of the substrate (as set forth above under IV.2), in the membrane of D1 the permeability for the substrate must be kept on a low value to achieve a linear relationship between the measures [sic] currency and the substrate concentration in the test solution. Rather, in accordance with column 5, lines 30 to 33 of the patent in suit: "Optionally, but preferably when being used on live blood, a protective membrane surrounds both the enzyme and the mediator layers, permeable to water and glucose molecules." ${ }^{20}$

The bolded words are original to Medisense's brief. A similar passage in a subsequent brief added that:

It is submitted that this disclosure is unequivocally clear. The protective membrane is optional, however, it is preferred when used on live blood in order to prevent the larger constituents of the blood, in particular erythrocytes from interfering with the electrode sensor. Furthermore it is said, that said protective membrane should not prevent the glucose molecules from penetration, the membrane is "permeable" to glucose molecules. This teaches the skilled artisan that, whereas the semipermeable membrane of D1 must be constructed, for example by crosslinking, in such a way that the membrane will in fact control the permeability of the glucose at the required low value, the purpose of the protective membrane in the patent in suit is not to control the permeation of the glucose molecules. For this very reason the sensor electrode as claimed does not have (and must not have) a semipermeable membrane in the sense of D1. ${ }^{21}$

\footnotetext{
${ }^{20} \mathrm{Id}$.

${ }^{21} \mathrm{Id}$. at 1109 .
} 


\section{A. The Case}

The three passages quoted above formed the centerpiece of the Therasense bench trial on the issue of inequitable conduct. As noted in the Introduction, inequitable conduct is a judicially created doctrine designed to punish patent applicants who behave inappropriately during patent prosecution, which is the ex parte process of obtaining a patent. ${ }^{22}$ There are three aspects to an inequitable conduct assertion: first, an act or omission on the part of the patent applicant that is material to the decision to allow a patent to issue; ${ }^{23}$ second, the material act or omission must have been done with the intent to deceive the patent office; ${ }^{24}$ and third, assuming materiality and intent to deceive have been found, a court must weigh the equities to determine whether the patent applicant's conduct warrants the sanction of inequitable conduct: patent unenforceability. ${ }^{25}$

22 For significant scholarship on inequitable conduct, see, for example, Christopher A. Cotropia, Modernizing Patent Law's Inequitable Conduct Doctrine, 24 BERKELEY TECH. L.J. 723, 766 (2009); Thomas Cotter, An Economic Analysis of Patent Law's Inequitable Conduct Doctrine, 53 ARIZ. L. REV. 735 (2011); Lisa Dolak, The Inequitable Conduct Gyre Widens, 50 IDEA 215 (2010); Robert J. Goldman, Evolution of the Inequitable Conduct Defense in Patent Litigation, 7 HARV. J.L. \& TECH. 37 (1993); John F. Lynch, An Argument for Eliminating the Defense of Patent Unenforceability Based on Inequitable Conduct, 16 AIPLA Q.J. 7, 8 (1988); Christian E. Mammen, Controlling the "Plague": Reforming the Doctrine of Inequitable Conduct, 24 BERKELEY TECH. L.J. 1329, 1332 (2009); David McGowan, Inequitable Conduct, 43 LOY. L.A. L. REV. 945 (2010); Sean M. O'Connor, Defusing the “Atomic Bomb” of Patent Litigation: Avoiding and Defending Against the Allegations of Inequitable Conduct After McKesson et al., 9 J. Marshall ReV. InTEll. Prop. L. 330 (2010); and Lee Petherbridge et al., The Federal Circuit and Inequitable Conduct: An Empirical Assessment, 84 S. CAL. L. REV. 1293, 1308-19 (2011). See also Christopher A. Cotropia et al., Do Applicant Patent Citations Matter? Implications for Presumption of Validity (Stanford Law \& Econ. Olin Working Paper Grp., Working Paper No. 401, 2010), http://ssrn.com/abstract=1656568 (studying the use of applicant-submitted prior art).

${ }^{23}$ Molins PLC v. Textron, 48 F.3d 1172, 1178 (Fed. Cir. 1995) ("Inequitable conduct includes affirmative misrepresentation of a material fact, failure to disclose material information, or submission of false material information, coupled with an intent to deceive. . . . One who alleges inequitable conduct arising from a failure to disclose prior art must offer clear and convincing proof of the materiality of the prior art.").

${ }^{24}$ Digital Control, Inc. v. Charles Mach. Works, 437 F.3d 1309, 1319 (Fed. Cir. 2006) ("[T]he involved conduct, viewed in light of all the evidence, including evidence of good faith, must indicate sufficient culpability to require a finding of intent to deceive.") (quoting Paragon Podiatry Lab., Inc. v. KLM Labs., Inc., 984 F.2d 1182, 1189 (Fed. Cir. 1993)).

${ }^{25}$ Star Scientific, Inc. v. R.J. Reynolds Tobacco Co., 537 F.3d 1357, 1365 (Fed. Cir. 2008) (" $[\mathrm{T}]$ he district court must still balance the equities to determine whether the applicant's conduct before the PTO was egregious enough to 
At the heart of the trial lay the issue of whether Medisense's argument to the European Patent Office that the "[o]ptionally, but preferably" sentence in the ' 636 meant that using any membrane at all was unnecessary or whether the argument instead related only to the type of membrane in the D1 reference. The accused infringers asserted the former: that the passages were inconsistent with Pope and Sanghera's assertions to the U.S. Patent Office and thus, because there was no dispute that Pope and Sanghera were aware of the '636 proceedings, the failure to disclose the fact that Medisense, in defending the '636 patent in Europe, had taken a position directly contradictory to the argument that it made to secure the allowance of the '551 patent in the U.S. amounted to an intent to deceive. ${ }^{26}$ On the other side, Abbott argued that the passages were not inconsistent or contradictory and provided lengthy testimony from Pope and Sanghera explaining what they understood the relevant statements to mean and why they did not disclose the European proceedings to the U.S. Patent Office. $^{27}$

The outcome of the trial did not favor Abbott. ${ }^{28}$ The district court agreed with the defense, holding that the statements should have been disclosed under 37 C.F.R 1.56, arguably one of the broadest of several Federal Circuit-sanctioned frameworks for analyzing materiality. ${ }^{29}$ Rule $1.56(\mathrm{~b})$ states that information is material to patentability when:

(1) It establishes, either by itself or in combination with other information, a prima facie case of unpatentability of a claim; or (2) It refutes, or is inconsistent with, a position the applicant takes in

(i) Opposing an argument of unpatentability relied on by the Office, or (ii) Asserting an argument of patentability. ${ }^{30}$

warrant holding the entire patent unenforceable.”) (citing Monsanto Co. v. Bayer BioScience N.V., 363 F.3d 1235, 1239 (Fed. Cir. 2004)).

${ }^{26}$ This was the view adopted by the District Court. See Therasense, 565 F. Supp. $2 \mathrm{~d}$ at $1112-16$.

${ }^{27} I d$.

${ }^{28} I d$.

${ }^{29} 37$ C.F.R. $§ 1.56$ (2000); see Digital Control, 437 F.3d at 1316 ("In this case, the district court, faced with the two versions of Rule 56, determined that the new Rule 56 standard was essentially the same as the 'reasonable examiner' standard" (the pre-1992 version of Rule 1.56)); cf. Am. Hoist \& Derrick Co. v. Sowa \& Sons, Inc., 725 F.2d 1350, 1363 (Fed. Cir. 1984) (commenting that the (pre-1992) Rule 1.56 standard "appears to be the broadest, thus encompassing the others").

${ }^{30} 37$ C.F.R. $\S 1.56(b)(2000)$. 
After deciding that the statements were material because they were "flatly inconsistent with the main point being made by Attorney Pope and Abbott to [the patent office]," the judge found that both Pope and Sanghera intended to deceive the patent office by failing to disclose the ' 636 proceedings. The trial court based its decision on the reasoning that both "knew or should have known that the withheld information would have been highly material to the examiner", and "had no plausible reason for consciously withholding the EPO submissions." "32 The court further found that Pope and Sanghera lacked credibility at trial. Given the court's finding of both high materiality and intent to deceive, it entered a judgment of inequitable conduct, subsequently awarding the accused infringers millions in attorneys' fees. ${ }^{33}$

Abbott appealed to the Federal Circuit, challenging the judgment of inequitable conduct. ${ }^{34}$ The appeal received a forceful rejection from two of the three judges assigned to the case. Judge Dyk, writing for himself and Judge Friedman, rejected each of Abbott's arguments in turn. Applying, as the district court did, Rule 1.56, Judges Dyk and Friedman found the district court's conclusion about the inconsistency not only "not clearly erroneous," but "manifestly correct." 35 According to the court, "To deprive an examiner of the EPO statements - statements directly contrary to Abbott's representations to the PTO — on the grounds that they were not material would be to eviscerate the duty of disclosure." $" 36$

On the subject of intent, the majority likewise affirmed the district court, concluding that, given the high materiality of the EPO statements coupled with Pope and Sanghera's knowledge of them, the lack of a credible explanation for their withholding was a sufficient basis to infer intent to deceive. Moreover, the majority held that the trial court's credibility determination was "virtually

\footnotetext{
${ }^{31} I d$.

${ }^{32} I d$.

33 The district court awarded BD/Nova approximately $\$ 6$ million in attorneys' fees, and while Bayer and Abbott settled the fee award for an undisclosed amount, Bayer's initial fee petition sought approximately $\$ 12$ million. See Order re Award of Attorney's Fees, Therasense, Inc. v. Becton Dickinson \& Co., No. C04-2123 WHA, (N.D. Cal. Mar. 19, 2009); Declaration of Jason Bartlett in Support of Bayer's Petition for Attorneys' Fees and Costs, Abbott Diabetes Care Inc. v. Roche Diagnostics Corp., No. C05-3117 WHA, (N.D. Cal. Sept. 25, 2008); Stipulation Regarding Fees Claimed by Bayer, Abbott Diabetes Care Inc. v. Roche Diagnostics Corp., No. C05-3117 WHA, (N.D. Cal. Dec. 4, 2008).

${ }^{34}$ The appeal also challenged a related finding of obviousness based on the ' 382 patent. Therasense, Inc. v. Becton Dickinson \& Co., 593 F.3d 1289, 1293 (Fed. Cir. 2010).

${ }^{35}$ Id. at 1303 .

${ }^{36}$ Id. at $1304-5$.
} 
unreviewable." ${ }^{37}$ The court, accordingly, affirmed the district court's judgment of inequitable conduct.

The panel's decision was not unanimous, however. Judge Linn issued a strong dissent in which he rejected both the trial judge's finding of materiality and the trial judge's findings concerning intent to deceive. ${ }^{38}$ In Judge Linn's view the statements were not inconsistent under precedent requiring that the "most reasonable inference" be drawn from a set of facts, nor could Pope and Sanghera's explanations be declared implausible based solely on the reasoning that the references themselves were objectively material. ${ }^{39}$ Three months later, the Federal Circuit granted Abbott's petition for rehearing en banc. The scope of the order for rehearing was unprecedented in the history of the doctrine, and suggested that the court was willing to reconsider almost anything and everything about the requirements of inequitable conduct. ${ }^{40} \mathrm{An}$ overwhelming number of amici responded, submitting at least 39 briefs advocating a range of options, including the elimination of the doctrine altogether. Most suggested some form of modification or clarification of the materiality or intent elements of the existing analysis. ${ }^{41}$

\section{B. The En Banc Opinion}

On May 25, 2011, the court issued an opinion that sought to radically reshape the landscape of inequitable conduct. ${ }^{42}$ The result was as close as any opinion the court had previously issued. On materiality, six judges - including Judge Jimmie V. Reyna, who had joined the court just a month and a half earlier - voted to require "but for" materiality, a standard that the court intends to be much stricter than the patent regulation-driven standard that had traditionally governed. ${ }^{4}$

Under a "but for" standard, materiality is only established if

${ }^{37}$ Id. at 1306 (quoting Hambsch v. Dep't of the Treasury, 796 F.2d 430, 436 (Fed. Cir.

1986)).

${ }^{38}$ Id. at 1312-24 (Linn, J., dissenting).

${ }^{39} \mathrm{Id}$.

${ }^{40}$ Therasense, Inc. v. Becton Dickinson \& Co., 374 Fed. Appx. 35 (Fed. Cir. Apr. 26, 2010) (nonprecedential). The Order posed six questions, including such fundamental topics as "Should the materiality-intent-balancing framework for inequitable conduct be modified or replaced?" and "If so, how?" Id.

${ }^{41}$ See Joy Bala, Note, Amicus Briefs: Sounding off on Reforming Inequitable Conduct, 45 LOY. L.A. L. REV. 125 (2011) (collecting, reporting, and analyzing the positions of the amici in the Therasense case).

${ }^{42}$ Therasense, Inc. v. Becton Dickinson \& Co., 649 F.3d 1276 (Fed. Cir. 2011) (en banc).

${ }^{43}$ Id. at 1291. 
the patent would not have issued but for the alleged material act. For example, if an applicant fails to disclose prior art during the prosecution, "that prior art is but-for material if the PTO would not have allowed a claim had it been aware of the undisclosed prior art." 44 Of course, the majority commented, "but for" materiality implicates the relevant legal rules for the patent application process, not those of an infringement action. Thus, when making the assessment, courts must apply a preponderance of the evidence standard (as opposed to a clear and convincing standard) and give claims their broadest possible construction (as opposed to applying the Federal Circuit law that governs the determination of patent claim scope). ${ }^{45}$

The court's new materiality standard is subject to a crucial exception, however: "When the patentee has engaged in affirmative acts of egregious misconduct, such as the filing of an unmistakably false affidavit, the misconduct is material." 46 Adding another layer, the exception is subject to its own exception: "[N]either mere nondisclosure of prior art references to the PTO nor failure to mention prior art references in an affidavit constitutes affirmative egregious misconduct." 47

Just as the majority specified a stricter standard for materiality, so too did it raise the bar for establishing intent. Before Therasense, there was some uncertainty about the level of intent needed to establish culpability for violations of the duty of candor. In the opinion, the court specified that going forward, inequitable conduct will require a "specific intent" 48 to deceive the patent office: "[T]he accused infringer must prove by clear and convincing evidence that the applicant knew of the reference, knew that it was material, and made a deliberate decision to withhold it." 49 As before, intent must be established separate from materiality, viz. a district court may not infer intent solely from materiality.

\section{LAW AND Policy Issues RAISED BY THERASENSE}

The Federal Circuit's opinion in Therasense v. Becton Dickinson raises serious concerns for innovation law and policy.

${ }^{44} \mathrm{Id}$

${ }^{45}$ Id. at $1291-92$.

${ }^{46}$ Id. at 1292 .

${ }^{47} \mathrm{Id}$. at $1292-93$.

48 Id. at 1290 ("To prevail on a claim of inequitable conduct, the accused infringer must prove that the patentee acted with the specific intent to deceive the PTO.").

${ }^{49}$ Id. 
This Part of the Article identifies some of the concerns raised by the opinion and provides an early analysis of their significance. The analysis is loosely framed by the majority's instrumental claim that the holding of Therasense will favorably address "adjudication cost and complexity, reduced likelihood of settlement, burdened courts, strained PTO resources, increased PTO backlog, and impaired patent quality" ${ }^{\prime \prime}$ - a a veritable slam-dunk in terms of public benefit. As we demonstrate below, there are reasons to be concerned that Chief Judge Rader's opinion might be too sanguine in its predictions.

The analysis is organized as follows: Part A describes how the policy of Therasense is to shift rents from the public to the patent-seeking class, and discusses how the court's implementation of this policy can result in serious efficiency problems. Part B addresses the implications of the court's decision for patent quality. Part $\mathrm{C}$ considers the impact of the decision on patent litigation, including the prospect of a reinvigorated antitrust doctrine in patent law. Part D evaluates whether practitioners should perceive greater legal protection from inequitable conduct findings because of the decision and whether practitioners will no longer make large disclosures of prior art in the course of patent prosecution. Part E represents an attempt to synthesize the concerns and analysis laid out in more detail in Parts A through D.

\section{A. A Patent Handout}

From nearly any perspective, the Federal Circuit's holding in Therasense represents a naked attempt to shift economic rents from the public and the patent office to the patent bar and those who seek patents. Prior to Therasense, patent applicants were required to take due care when prosecuting patent applications. This in part meant that an applicant was required to disclose to the patent office information that the applicant knew about and which the applicant knew a reasonable examiner would have considered important in deciding whether to issue a patent. After Therasense, patent applicants no longer have this duty-at least to the extent courts will enforce it - unless the information at issue falls into a very narrow category. Specifically: information known to the patent applicant and unknown to the patent office that the applicant knows would cause the patent office to not allow the claims in an application to issue as a patent if disclosed. ${ }^{51}$ In addition, after

${ }^{50} I d$.

51 The court recognized an exception "in cases of affirmative egregious misconduct." This exception, according to the majority, emerges from a set of Supreme Court cases dealing with fraud and unclean hands in the context of patent acquisition and seems targeted generally at planned "scheme[s]' to defraud the PTO and the Courts." Id. (quoting Hazel-Atlas Glass Co. v. 
Therasense, a patent applicant must by his actions or omissions specifically intend to mislead the patent office into issuing claims it would not have otherwise issued, whereas before, a patent applicant could have had sufficient mental culpability if he knew or objectively should have known that his actions were misleading.

Because the court's holding pushes in the direction of reducing the care and patent quality responsibilities that applicants have in their dealings with the patent office, it is logical to predict that the court has made patent examination marginally less expensive for patent applicants. But making patenting cheaper by requiring less of patent applicants in the course of patent creation presents concerns, because it occurs in a context in which it is commonly accepted that (1) the patent office already does not have the resources to ensure that only deserving inventions receive patents, and (2) some of the costs of patent creation - in particular costs of information about what the invention is, how it relates to prior innovations, and often whether it actually meets the statutory requirements for patentability - are more efficiently borne by patent applicants. Thus, while the Therasense-encouraged shift in rents may be a good outcome for patent lawyers and for those who seek cheap patents, it may be less of a good outcome for the patent office, competitors, and the public.

Our reasoning is based on the stated purpose of the majority opinion. On its own terms, the holding of Therasense seeks to reduce the private resources devoted to patent examination. But unless one adopts the position that those private resources were in the past mostly wasted, in which case spending less on patent creation might be fine, someone must pay the cost if the same level of investment in patent creation is to be maintained. With patent applicants no longer paying as much of the cost of the patent creation process as they were before, the institution most likely called upon to compensate will be the patent office. Unfortunately, it is already conventional wisdom that the patent office cannot meet the investment that the pre-Therasense law required of it. ${ }^{52}$ In fact, the patent office argued directly against the new rules for inequitable conduct that the Federal Circuit imposed in Therasense. ${ }^{53}$ It is therefore difficult to expect that the patent office will increase its investment in the patent creation process to make up the difference.

In its quest to make patenting cheaper for patent applicants,

Hartford-Empire Co., 322 U.S. 238, 245 (1944)).

${ }^{52}$ See, e.g., Mark A. Lemley, Rational Ignorance at the Patent Office, $95 \mathrm{Nw}$. U. L. ReV. 1495, 1499-1500 (2001); Gideon Parchomovsky \& Michael Mattioli, Partial Patents, 111 Colum. L. ReV. 207, 215 (2011) (describing the increasing backlog at the patent office).

${ }^{53}$ See Therasense, 649 F.3d at 1305-06 (Bryson, J., dissenting). 
the Therasense majority also ignores almost entirely the concern that patent applicants are often the most efficient (i.e., lowest cost) providers of certain information important to the patent creation process. For example, some information will be readily available to the patent applicant due simply to the fact that the applicant may be a regular patent applicant in a particular industry. Other information may be at the applicant's fingertips because it is information the applicant discovered and utilized in determining how to address the innovation problem it confronted and that led to the patent application at issue. Still other information may be literally sitting on the applicant's desk because the applicant discovered it when preparing the patent application. In many instances, it will be cheaper for the applicant to provide this sort of information to the patent creation process than it will be for the patent office to discover the information on its own and appreciate its significance. ${ }^{54}$ And in some circumstances, this information may be uniquely (or nearly so) within the knowledge and control of the applicant.

When information pertaining to patentability is uniquely within the control of the patent applicant, the comparative efficiency gains in having the applicant provide the information can skyrocket. The information described above mostly concerns the innovation context of the invention. But there is other information outside the innovation context of the invention that is nonetheless crucial to the issue of patentability. Much of this other type of information, such as the timing of the invention, public uses and sales, and abandonments and the like, may be uniquely (or nearly so) within the control of the patent applicant. In many instances, it may be fairly inexpensive for the applicant to make the disclosure, although it may adversely affect the patentability of the claims the applicant seeks and thus increase the costs and fees that will be paid to a patent agent or attorney to negotiate the issuance of a patent. By contrast, it is much more expensive-in practical terms approaching infinity-for the patent office to bring information uniquely within the control of the applicant to bear on the patent creation process.

The majority's purpose in Therasense is to make patent creation cheaper for the patent bar and for those who seek patents. The savings comes in the form of requiring from patent applicants less care in the patent creation process and a lower contribution to patent quality. Therasense is therefore a patent handout. Reflected back against the court's claims for the Therasense holding, the

${ }^{54}$ We recognize that applicants do not have a duty to search the prior art. The information we are discussing in this section is information that the applicant, viz. inventors, attorneys or agents, and everyone else substantively involved with the application, already has in its possession. 
above discussion raises concerns about whether Therasense really will favorably address "strained PTO resources." patent office attempts to add resources to the patent creation process to compensate for those that private parties are now able to retain, it is possible that exactly the opposite will happen: patent office resources may become more strained than they were before. ${ }^{56}$ And if the patent office does not find some way to pick up the tab for the private savings, then it is likely that the public will, in the form of inefficiently higher prices for goods and services. The reason for this is that more low quality patents might be expected as a consequence of the Therasense decision. It is to that issue that we turn next.

\section{B. Implications for Patent Quality}

There has been much hue and cry in the last decade about the quality of patents, viz. a conventional wisdom has developed that many patents issue from the patent office that should not have issued because the inventions disclosed and claimed in the patents do not satisfy the statutory requirements for patentability. ${ }^{57}$ The

${ }^{55}$ Therasense, 649 F.3d at 1290.

${ }^{56}$ It must be noted that the Therasense opinion did not render the patent office legally helpless when it comes to enforcing the duty of candor imposed by the patent regulations. The office might still enforce Rule 56 on its own. It might also raise patent application fees and maintenance fees; the net effect of such a strategy could be to take back some of the profits that the Federal Circuit handed to patent applicants in Therasense, although such a strategy should be expected to be less efficient for reasons discussed above, as well as for the reason that the costs will not be nearly as specifically targeted to the parties that impose them. Another alternative still is for the patent office to demand, through Rule 105 requests, the same kind of information Rule 56(b) requires of applicants. Failure to respond truthfully to such requests can result in abandonment. See Star Fruits S.N.C. v. United States, 393 F.3d 1277 (Fed. Cir. 2005); see also Lee Petherbridge, Positive Examination, 46 IDEA 173 (2006) (arguing for the use of rule 105 by the patent office to gather information from patent applicants about the invention for which a patent is sought). Another possibility is the increased use by the government of 18 U.S.C. $\S 1001$ (2006), which makes it a crime to "knowingly and willfully" make a "materially false ... statement" or "conceal . . . a material fact" "in any matter within the jurisdiction of the executive, legislative, or judicial branch of the Government of the United States"; compare United States v. Markham, 537 F.2d 187 (5th Cir. 1976), which affirmed a conviction under 18 U.S.C. $\S 1001$ (2006) based on the act of attempting to conceal from the patent office the true inventor of the process for which a patent was sought.

${ }^{57}$ See, e.g., R. Polk Wagner, Understanding Patent-Quality Mechanisms, 157 U. PA. L. REV. 2135, 2138 (2009) (defining a low-quality patent). One of the many excellent comments we received from practitioners in connection with an earlier draft of this Article raises the concern that even assuming that patent applicants use the Therasense decision to avoid disclosing information that could either lead to a rejection or be invalidating in its own right, would not patent quality 
opinion for the court boldly asserts that Therasense will favorably address "impaired patent quality." 58 While the future is not yet written, we develop an analysis below that suggests that such a claim might turn out to be incorrect. We suggest instead that after Therasense, for those not cynical enough to believe that patent quality is already hopelessly low, it is reasonable to expect the quality of patents to suffer even more than it already does. The main reason is that the patent office, which is already thought to be fairly poorly informed when it determines patentability, will be even less well-informed about the invention, the relevant art, and other facts that relate to the technicalities of applying the statutory standards for patentability. In other words, the patent office will be even more in the dark when conducting patent examination after Therasense than it was before. In the words of the patent office (referring to earlier efforts on the part of the patent bar to impose a standard like the one the Federal Circuit imposed in Therasense):

The suggested "but for" standard would not cause the Office to obtain the information it needs to evaluate patentability so that its decisions may be presumed correct by the courts. If the Office does not have needed information, meaningful examination of patent applications will take place for the first time in an infringement case before a district court. Courts will become increasingly less confident of the Office's product if they get the impression that practitioners and inventors can routinely withhold information from the Office, or that practitioners and inventors can make up their own minds about what is patentable. ${ }^{59}$

It is common ground to most who study the patent system

nonetheless be protected by the threat of a determination of invalidity in view of the art that was not disclosed? We think the answer is, yes, partially; but only partially. We do not dispute that low quality patents can be eliminated by litigation. But invalidating a patent in litigation can be expensive, even if it occurs at the summary judgment stage. In addition, litigating a patent that should not have issued is, at some level, a waste of money. It is a waste for the patent office to examine; it is a waste for a competitor to have to defend against; and it is a waste of judicial resources. Furthermore, an invalid patent might still serve a sterile anti-competitive purpose because it allows a patent holder to inflict costs on a competitor. Finally, in the United States, the showing required to invalidate a patent is, formally at least, somewhat high. Patents are presumptively valid and must be proved invalid by the clear and convincing evidence. See Microsoft Corp. v. i4i Ltd. P'ship, 131 S. Ct. 2238 (2011).

${ }^{58}$ Therasense, 649 F.3d at 1290.

${ }^{59}$ Duty of Disclosure, 57 FED. REG. 2020, 2024 (Jan. 17, 1992) (to be codified at 37 C.F.R. pts. 1, 10). 
that when patents are issued for inventions that do not satisfy the requirements of patentability there are competitive costs to be paid. ${ }^{60}$ The reason is that the patent system is itself not costless. By creating private property for limited times in inventions, the patent system both confers benefits and imposes costs. The benefits are often touted; the main one being the optimization of the production of new and useful information, a generally non-rivalrous and nonexcludable good that theory suggests will be underproduced without some kind of positive interference in the market. The costs of a patent system, on the other hand, include the supramarginal cost pricing that may be imposed when patents are used-as they were intended - to reduce competition in a market.

Because of the competitive impact of patents, patent policy has long been chary of patents that do not meet the requirements of patentability. Stated generally, the reasons are straightforward. Low-quality patents - those that should not have issued because they do not meet the statutory requirements for patentability-may give patentees some pricing power in instances where the patentee has not given the public sufficiently valuable new and useful information. It is, in a sense, money for nothing (or at least money for not a good enough something). The result is that competitors and the consuming public pay more for goods and services than they need to, patentees profit more from the patent system than policy requires, and the efficiency benefits of competition are not optimized. Indeed, the Therasense case arguably embodies this very concern: the Federal Circuit concluded that the '551 patent apparently should not have issued in view of the 382 patent (according to the court, it was not an invention over existing information-in patent parlance, it was obvious when the application was filed). Assuming the court's analysis is correct, diabetics using products that were embodiments of the invention claimed in the '551 patent might have been paying too much for their treatment, not to mention the fact that research into new innovations for diabetics might also have been marginally suppressed. $^{61}$

As discussed at length in the previous part, the direction of the Therasense holding is to require from patent applicants less care in and less contribution of information to the patent creation process. Given the sort of information that may go missing, discussed ante in Part II.A, it is reasonable to suspect that the marginal quality of information brought to bear on the patentability

${ }^{60}$ See, e.g., Jay P. Kesan \& Andres A. Gallo, Why "Bad" Patents Survive in the Market and How Should We Change?-The Private and Social Costs of Patents, 55 EMORY L. J. 61, 77 (2006).

${ }^{61}$ We use this merely as a hypothetical example of patent theory, and do not mean to suggest that this is what actually occurred for this specific patent. 
determination by the patent office will be poorer. However, little else about the patent granting process has changed. When an applicant files an application and pays a fee, it is presumably entitled to a patent unless the patent office can successfully demonstrate why it is not. ${ }^{62}$ This reinforces the interpretation that patent quality may be discouraged, rather than encouraged, by the Federal Circuit's decision in Therasense, because the patent office will not have the information it needs to lawfully reject patent claims. $^{63}$

Not only might patent quality suffer because of Therasense, but, less able to distinguish deserving applications from undeserving ones, examiners might also more often reject claims that should be allowed. The effect of this eventuality, should it come to pass, would be to reduce the public's access to new innovations. Spurious rejections of claims to meritorious inventions also damage the incentive structure of the patent system by discouraging some set of potential innovators from innovating or disclosing their innovations.

Obviously, whether Therasense will have a positive impact on patent quality, as the court's opinion predicts, remains to be seen. Our analysis suggests that it is at least possible that that prediction may prove incorrect. Indeed, Therasense could encourage exactly the opposite outcome: low-quality patents might become even more prevalent than they were before, and inventors of genuine innovations - the sort policy desires to encourage with the patent system--might even be marginally discouraged.

If more low-quality patents issue because of Therasense, then one might anticipate - as the patent office did years ago ${ }^{64}$-that there will be consequences to patent litigation. In the next Part, we consider the majority's claim about the salutary benefits of Therasense on patent litigation.

\footnotetext{
${ }^{62}$ See Lemley, supra note 53, at 1500.

${ }^{63}$ Thus, while we are cognizant that there may be a point of diminishing returns in terms of the level of examination provided by the patent office, see $i d$. at 1498-1500 (pointing out that we cannot afford perfection in patent office determinations), we think that this threshold has not yet been reached, at least with respect to the information that is the subject of inequitable conduct. First, there is evidence that the rate at which patents are commercialized is substantial. See Jason Rantanen et al., America Invents, More or Less?, 160 U PA. L. REV. PENNUMBRA 229, 242 (2012) (reporting aggregate data of five to fifty percent of patents being commercialized). Second, the type of information that is the subject matter of inequitable conduct is precisely the type of information that is most beneficial to the patentability determination when disclosed by the applicant. See Jason Rantanen \& Lee Petherbridge, Toward a System of Invention Registration: The Leahy-Smith America Invents Act, $110 \mathrm{MICH}$. L. REV.: FIRST IMPRESSIONS 24, 27-28 (2011).

${ }^{64}$ See supra note 60.
} 


\section{Implications for Patent Litigation}

The opinion for the court makes a number of claims about the salutary impact of the Therasense holding on patent litigation. In particular, the court declares that the holding will favorably address the "increased adjudication cost and complexity, reduced likelihood of settlement, [and] burdened courts" ${ }^{\prime \prime 5}$ that arose from the pre-Therasense inequitable conduct jurisprudence. In this Part, we use theoretical logic and common sense to develop an analysis that challenges the claim that Therasense will have an efficiencyenhancing impact on patent litigation. We emphasize four specific points. First, if Therasense encourages more low quality patents, that fact may adversely impact the amount and intensity of patent litigation. Second, Therasense did not get rid of patent acquisition misconduct doctrine - instead, it might even have made it more complex and dangerous to patent practitioners and the patent system's reputation. Third, Therasense adjusts the risk incentives of the patent bar, and the expectations for agent risk-taking of those who seek patents. Fourth, building on the third point, we explain that if the majority's holding ends up permitting conduct that competitors find inappropriate, something akin to moral outrage at patent applicant behavior may encourage competitors to more intensely pursue litigation than they might otherwise. This effect may be enhanced by the effective convergence of the requirements for inequitable conduct and Walker Process fraud.

The previous Part discusses many of the concerns raised by the prospect that Therasense may encourage low-quality patents, so here we will be brief. We postulate two things: (1) more lowquality patents issued by the patent office means that more patent enforcement actions will involve low-quality patents, and (2) when faced with a claim of infringement based on a low-quality patent, a competitor will resist liability more vigorously than when faced with a high-quality patent. Our point here resolves to a simple logical syllogism: if Therasense increases the amount of low quality patents, then competitors will (at least on the margins) spend more to resist the enforcement of patents. ${ }^{66}$ If that turns out

${ }^{65}$ Therasense v. Becton Dickinson \& Co., 649 F.3d 1276, 1290 (Fed. Cir. 2011).

${ }^{66}$ Note that we accept that patent litigation is mostly an economic exercise, viz. that when it makes sense to spend money defending the suit, defendants will do so; when it does not make economic sense, they probably will not. On this point, we offer two thoughts: first, we speculate that because of Therasense, there will develop marginally more cases where it makes sense for defendants to spend more resources resisting the enforcement of a patent; second, because of Therasense, defendants will face enforcement actions involving patents that would not have been available for enforcement in a pre-Therasense legal context. 
to be the case, and if patent enforcers are unwilling to back down, then Therasense may well increase adjudication cost instead of reducing it as the court's opinion predicts.

Another reason that Therasense may not favorably address "increased adjudication cost and complexity, reduced likelihood of settlement, [and] burdened courts" ${ }^{\prime 67}$ is that Therasense did not get rid of patent acquisition misconduct doctrine. Although it appears entirely unappreciated by the initial response to the case by the patent bar, Therasense arguably made patent acquisition more complex and dangerous to patent practitioners. Before Therasense, only one patent acquisition misconduct doctrine was substantially used in patent litigation. After Therasense, there are potentially three separate legal theories that must be analyzed when a claim based on misconduct during patent prosecution is made.

The first theory is the doctrine of unclean hands, a defense that was probably so unused that its reawakening by the Federal Circuit is likely the equivalent of raising it from the dead. Perhaps it was unavoidable, but as the court sought to place limits on the doctrine of inequitable conduct, it discussed and then set aside this old Supreme Court doctrine as untouchable. In so doing, the majority may have inadvertently reinvigorated it by the explicit recognition of its viability. Thus, even before getting to the question of inequitable conduct, one might expect accused infringers to assert unclean hands, which, as the majority noted, "remains available to supply a remedy for egregious misconduct like that in the Supreme Court cases."

In addition to reviving an unclean hands defense, the majority's framework for inequitable conduct itself necessitates two distinct assessments of materiality: the "but for" invalidity analysis and the "affirmative egregious misconduct" (solely before the patent office) analysis. Peeling back yet another layer, the "but for" determination requires the court to assess validity against the patent office's standards for allowing patents-standards the district courts are unfamiliar with applying in patent cases - rather than the standards that typically apply when conducting infringement proceedings in district courts. Thus, for example, claim scope in patent litigation has for decades been determined according to rules laid down by the Federal Circuit. A district court, when determining patent infringement, patent invalidity, and a host of other patent-related questions must still apply those rules. Moreover, when district courts apply the substantive law of infringement and invalidity, they will be applying it to facts developed in anticipation of that law in the context of the clear and

${ }^{67}$ Therasense, 649 F.3d at 1290.

${ }^{68} \mathrm{Id}$. at 1287. 
convincing evidence standard.

However, when a district court turns its attention to inequitable conduct, it must now change gears and apply different legal rules in the context of a different standard of proof. Rather than apply, for example, the familiar law of patent claim construction, district courts will be asked to determine patent claim scope for inequitable conduct purposes by applying the standard that the patent office uses, viz. courts should give patent claims their "broadest reasonable construction" (instead of the construction they have received for the rest of the litigation). Next, courts will need to determine not whether the patent claims properly construed are invalid, but instead whether the patent office would have allowed the claims to issue as a patent. Moreover, courts will be applying that novel standard in the context of a burden of proof different from that with which they and patent litigants are ordinarily familiar, namely, in the postTherasense world courts and litigants must operate in the context of a preponderance of the evidence standard (as opposed to the traditional clear and convincing evidence standard). ${ }^{69}$ This framework raises obvious issues about the complexity and substantive accuracy of patent acquisition misconduct litigation going forward.

This new, multi-layered inequitable conduct framework may also add to litigation costs and burdens in other ways. For example, the new structure might strongly encourage additional trials on inequitable conduct. Prior to Therasense, separate trials on inequitable conduct (as opposed to questions of validity and infringement) were sometimes held due to the concern that inequitable conduct claims could poison juries addressing the broader issues involved in the infringement proceeding. ${ }^{70}$ Under the Therasense framework, however, the analysis courts must undertake to determine inequitable conduct seems to have become more, rather than less, complex and involved so that not only do the traditional issues of prejudice still exist, but there will be additional issues about which prejudice will be a concern and about which jurors and jurists can get confused. Thus, the need to analyze inequitable conduct claims under a wholly separate set of legal standards than those that apply to the rest of patent litigation raises the specter of an increase rather than decrease in the requirement of double trials.

Another unintended consequence of the need to apply two different patent scopes in a single patent litigation may be that doing so will give the accused infringer a second bite at the apple.

${ }^{69} \mathrm{Id}$. at $1291-92$.

${ }^{70}$ See, e.g., Gardco Mfg., Inc. v. Herst Lighting Co., 820 F.2d 1209 (Fed. Cir. 1987). 
Accused infringers will first be able to advocate a claim construction that favors their invalidity positions and then, if the court rules against them, will be able to assert inequitable conduct claims based on their broad, putatively "reasonable" construction.

Given these concerns, it is at least possible, if not likely, that the new framework articulated by the majority will not reduce the cost or complexity of individual determinations of inequitable conduct allegations. ${ }^{71}$

A third concern presented by Therasense that impacts patent litigation is the concern that the opinion adjusts the risk incentives of the patent bar, and the expectations for agent risktaking of those who seek patents. Attorneys naturally push the boundaries of the law-it is their job, after all. Even patent attorneys, who have long cultivated the image of neutral participants in the patent application process, are nevertheless ethically obligated to advocate on behalf of their clients. ${ }^{72}$ Yet with Therasense, the veneer of being a neutral participant in an ex parte proceeding has largely been stripped away, and it is reasonable to expect that no matter how noble the person, attorneys involved in patent acquisition will act more like their counterparts in other fields, aggressively jockeying for the most advantageous outcome for their clients. ${ }^{73}$

It is therefore reasonable to suspect that Therasense may encourage patent applicants and attorneys to engage in riskier

${ }^{71}$ We also question the impact that inequitable conduct really has on discovery costs, an assertion for which there is at present a lack of empirical evidence. Nor do we see much of a change in this area as a result of Therasense, in part, we speculate, because limits on the scope of discovery are often a function of the tolerances of the parties and the relevant judge as opposed to the specific legal theories advanced. Moreover, even without the doctrine of inequitable conduct, many other patent law doctrines permit and invite an inquiry into the patent holder's documents that goes well beyond the documentation necessary to support conception and reduction to practice. To take just the example given by the majority, that "[a] charge of inequitable conduct conveniently expands discovery into corporate practices before patent filing," that same discovery can be justified under a number of doctrines, from challenging best mode to exploring patent ownership issues to contesting objective evidence of nonobviousness. Therasense, 649 F.3d at 1288. Indeed, a more important tool for limiting the discovery costs of inequitable conduct probably existed before Therasense. Inequitable conduct is required to be pled with particularity. Until it is, a patent holder's counsel may be able to successfully oppose some inequitable conduct-related discovery on the ground that it is irrelevant. In short, while inequitable conduct may be an arrow in the litigation discovery counsel's quiver, it is by no means the only one, or even the most potent in most cases.

${ }^{72}$ MODEl RULES OF PROF'L CONDUCT Preamble (1983).

${ }^{73} \mathrm{We}$ do not mean to suggest that all patent attorneys and agents engage in risky behavior. But when one looks at the incentives that Therasense creates, they unquestionably lean in favor of permitting riskier behavior when it comes to obtaining a patent. 
behavior-to move closer to the new line that the court has drawn as the boundary of acceptable behavior. Today's egregious conduct may become tomorrow's run-of-the-mill inequitable conduct allegation, while yesterday's inequitable conduct will become tomorrow's mandatory practice. For reasons already discussed, and for some that follow, there is little reason to think that this shift in risk incentives will result in fewer charges of inequitable conduct. Instead, a more likely consequence might be that future charges will reflect claims of much uglier and more serious misconduct than courts regularly see today.

A final point to raise also involves adjusted risk incentives. Inequitable conduct (or patent misconduct litigation) may, over time, be stimulated by Therasense, because the conduct Therasense might protect as "acceptable" might normatively be seen as unacceptable by some patent lawyers and by defendants in patent litigation suits. If so, defendants might vigorously pursue inequitable conduct claims even in the face of unfavorable rules.

At bottom, this point is about rules not aligning well with norms. It is quite conceivable that some inequitable conduct charges are not really about technical violations of rules laid down by the Federal Circuit. Rather, they may be driven by a litigant's or a judge's moral view of right and wrong - a a moral compass, if you will. Unlike the rules of inequitable conduct, this normative standard may be harder to move with a Federal Circuit opinion, especially among district court judges, whose moral compasses may have a fixed bearing as a result of their exposure to a range of misconduct charges from outside the boundaries of patent law.

So while patent attorneys, and perhaps even the Federal Circuit, may see that the rules of Therasense permit certain forms of conduct that previously were prohibited, that conduct may still be perceived as "wrongful" by district court judges and other front line decision makers. And if, as we speculate above, future inequitable conduct claims involve behavior that is more readily perceived as morally wrongful, front line decision makers may be inclined to let those claims proceed all the way through to trial, rather than summarily dismissing them.

The gravity of this point is augmented when one realizes that after Therasense, the requirements of inequitable conduct have largely converged with the requirements for an antitrust claim based on Walker Process fraud. ${ }^{74}$ Prior to Therasense, the bench

${ }^{74}$ Herbert J. Hovenkamp, Patent Exclusions and Antitrust After Therasense 34 (U. Iowa Legal Stud. Res. Paper, No. 11-39, 2011), http://ssrn.com/abstract=1917074. Under the Supreme Court's decision in Walker Process Equipment Inc. v. Food Machinery and Chemical Corp., 382 U.S. 172 (1965), a patent holder may be liable under antitrust laws for filing a patent infringement suit in order to exclude a rival if the patent was obtained 
and bar recognized that the degree of conduct necessary to render a patent unenforceable for inequitable conduct was less than that needed to support an antitrust claim. ${ }^{75}$ After Therasense, there is considerable doubt that this statement is still correct. ${ }^{76}$ If true, it means that post-Therasense, inequitable conduct claims are more likely to provide a sound basis for antitrust claims than before. ${ }^{77}$

The end result might be greater costs and greater complexities in patent litigation.

\section{Implications for Patent Practitioners}

By its own terms, the Federal Circuit's Therasense opinion seeks to help patent practitioners. In this Part, we consider whether the patent bar and those who seek patents secured at least something substantial from the court's opinion. Put differently, did the Therasense opinion substantially address the claims and concerns that patent practitioners generally made and pressed in connection with the en banc case? Or might there be reason to think that the majority's opinion will fail to bring the promised relief? If the latter, the concerns developed in the prior Parts of this Article about the impact of the court's opinion on the patent system as a whole might not find much equilibration through the cost savings the court sought to give to patent applicants.

This Part proceeds by first considering whether the Therasense opinion should be expected to have the impact the court anticipates on case outcomes, and then moves to an analysis of whether it should be expected to have the impact the court anticipates on patent prosecution behavior. Our analysis suggests a disturbing probability. There is reason to believe that the Therasense opinion may have little specific impact on case outcomes, namely that it is not the prophylactic against findings of

through fraud on the patent office. Hovenkamp, supra at 1.

${ }^{75} \mathrm{Id}$. at 33.

${ }^{76}$ As Professor Hovenkamp commented post-Therasense, "[the] statement that the degree of inequitable conduct necessary to invalidate a patent is not as great as the degree needed to support an antitrust claim was very likely overruled by Therasense's requirement that even inequitable conduct involves actual knowledge and intent to deceive. Once the inequitable conduct doctrine is recast this way there seems to be no room for a finding of 'greater' inequitable conduct in antitrust cases." Id. at 34.

${ }^{77}$ Not to overstate this point, Hovenkamp does identify a principal distinction between Walker Process antitrust claims and inequitable conduct claims: the former is based on actions and state of mind at the time a patent infringement action is filed, while the latter is based on actions and state of mind that occur during the patent prosecution process. This may lead to some circumstances in which a patent holder may be subject to a finding of inequitable conduct, but not an antitrust claim, and others in which the opposite may be true. Id. at 29. 
misconduct it has been trumpeted to be. In addition, we speculate that the holding might have little impact on the single most important concern raised by the patent bar and those who seek patents - a a perception that because of inequitable conduct doctrine patent applicants sometimes make costly disclosures of prior art that are entirely unimportant to a reasonable examiner in deciding patentability. Instead, the most significant impact of Therasense may only be that patent applicants have been given more leeway to determine unilaterally the statutory requirements for patentability in connection with prior art that is difficult or impossible for the patent office and competitors to learn about. Therasense may thus end up accentuating the negative aspects of the current scheme while providing little to no positive systemic benefits.

\section{Will Therasense Really Change Case Outcomes?}

We think it clear that the Federal Circuit thought it was making a sea change with its decision in Therasense. The early reaction from the bar and some commentators has been jubilation. ${ }^{78}$ A common sense has quickly developed that the decision will have the impact of helping to protect patents from claims that they were obtained inequitably, and by extension, helping to protect the reputations of the patent lawyers whose responsibility it is to procure patents from the patent office.

Perhaps the ultimate question for courts and lawyers, then, is whether the Federal Circuit's opinion will affect case outcomes: will Therasense work to change the outcomes in any particular case, and perhaps, will Therasense produce a systemic result of fewer findings of inequitable conduct than before? Certainly there is some reason for the patent bar's jubilant belief that case outcomes will be impacted. As we have already noted, the majority opinion clearly indicates the intent to make it more difficult to establish inequitable conduct. This signaling effect alone may be sufficient to cause trial judges to find inequitable conduct less

${ }^{78}$ See, e.g., Lawrence T. Kass \& Nathaniel T. Browand, 'Therasense': Vaccine for $a$ Plague, NAT'L L.J., June 6, 2011, http://www.law.com/jsp/nlj/PubArticleNLJ.jsp?id=1202496036951\&Therasense _Vaccine_for_a_plague\&slreturn=1\&hbxlogin=1; Nate Raymond, Federal Circuit Guts Inequitable Conduct Defense, Patent Plaintiffs Rejoice, AM. LAWYER, May 25, 2011, http://www.law.com/jsp/cc/PubArticleCC.jsp?id=1202495333432\&Federal_Cir cuit_Guts_Inequitable_Conduct_Defense_Patent_Plaintiffs_Rejoice. Law firms have issued similar commentary. See, e.g., Jeff Mills \& Brian Banner, Client Alert: Federal Circuit Makes it More Difficult to Prove Inequitable Conduct During Patent Prosecution, KING \& SPALdING LAW (May 31, 2011), http://www.kslaw.com/imageserver/KSPublic/library /publication/ca053111.pdf. 
often.

The formal framework constructed by the majority may also make it easier for patent holders to prevail on claims of inequitable conduct. Even leaving aside the arguably pro-patent holder language of the standards, the contraction of the preTherasense materiality standards to two formal articulations will perhaps force district courts to more clearly communicate their reasoning and will limit their ability to pick the standard that best suits the outcome they would like to achieve.

However, several considerations may be balanced against the view that Therasense will shift case outcomes in favor of patentees. The first is discussed at length in the earlier Part on Implications for Patent Litigation. ${ }^{79}$ The relevant points there are that Therasense has not eliminated patent acquisition misconduct doctrine, and may even have made it more complex and dangerous to patent practitioners. At the same time, Therasense might encourage prosecuting attorneys and agents to engage in riskier behavior. Indeed, professional obligations to clients might even require moving closer to the purportedly new line the court has drawn defining acceptable behavior.

A second consideration is that inequitable conduct findings are already very rare. ${ }^{80}$ In order to substantially reduce such findings, Therasense probably would need to impose a standard so strict as to make a finding of inequitable conduct essentially impossible. For the reasons discussed above, it seems unlikely that Therasense has done so, and even Judge Rader's opinion for the majority does not purport to go so far.

A final consideration is whether the analytical framework prescribed by Therasense really compels a different result in any specific case. In other words, can one at least rest easy that Therasense will predictably filter patent acquisition misconduct claims so that in most cases the behavior involved is, at least on average, "worse" than behavior that has in the past supported claims of inequitable conduct? Or, instead, is the Therasense doctrine just as susceptible to being shaped to fit the normative views of judges as the previous doctrinal incarnation of inequitable conduct? Below, we set forth some reasons why patent practitioners should worry that the same kinds of behaviors that have supported inequitable conduct findings in the past can easily

\footnotetext{
${ }^{79}$ See supra Section II.C.

${ }^{80}$ See Petherbridge, et al., supra note 22, at 18-29; Inequitable Conduct: 2005 2010, LEX MACHINA, https://lexmachina.com/reports/getfreereport (last visited June 17, 2011) (reporting 41 instances of inequitable conduct findings out of 13,786 total patent cases during the period 2005-2010); cf. Mammen, supra note 22, at 1354 (finding a trend of three to five inequitable conduct rulings a year for the prior four years to be abnormally high).
} 
be made to fit the doctrine announced in Therasense should a district judge be so inclined.

Of the majority's holdings, its materiality framework represents the most dramatic departure from the past, requiring that the relevant conduct now pass a "but for" test. Yet that requirement contains an exception: for "affirmative egregious misconduct." Although its contours have not yet been fully explored, that exception is perhaps so great that it swallows the whole. As the dissent notes, "it is often difficult to draw a line between nondisclosure and affirmative misrepresentation. . . . The distinction between 'affirmative acts' and 'nondisclosure' is thus apt to become fertile ground for litigation in the future, not to mention the distinction between 'egregious' misconduct and misconduct that is assertedly less than "egregious.", 81

The court's holding on the intent element is even more problematic in terms of mandating specific outcomes. On the relevant standard both the majority and dissent agreed: inequitable conduct requires specific intent to deceive the patent office. Rather than disagreeing about the applicable standard, the disagreement between the majority and dissent turns on a purely factual analysis: whether or not the relevant facts involved in this case, reviewed under a standard deferential to the District Court's findings, satisfy that legal standard. Notably, nowhere in the dissent's opinion does it take issue with the majority's legal statements about the applicable standard for intent.

What this dispute suggests to us is that the question of intent will continue to play a key role in the Federal Circuit's review of inequitable conduct determinations, ${ }^{82}$ and the court will continue to be sharply divided on this issue. Nothing in the dissent's opinion suggests that it views the legal pronouncements of the majority as limiting its ability to follow its normative views on whether or not particular conduct was intended to deceive the patent office.

We also note that the dissent already has a powerful doctrinal tool should it choose to express its normative views. Within days of the Federal Circuit's opinion in Therasense, the Supreme Court issued its opinion in Global-Tech v. SEB, ${ }^{83}$ a case dealing with the degree of scienter required for inducement of infringement. In Global-Tech, the Supreme Court concluded that knowledge for inducement can be established through "willful blindness" - a form of fault that appears to be novel to the patent

${ }^{81}$ Therasense, Inc. v. Becton Dickinson \& Co., 649 F.3d 1276, 1314 n.3 (Fed. Cir. 2011).

${ }^{82}$ See Petherbridge, et al., supra note 222 (empirically analyzing the importance of the intent to deceive element of inequitable conduct doctrine).

${ }^{83}$ Global-Tech Appliances, Inc. v. SEB S.A.,131 S. Ct. 2060 (2011). 
context. While the doctrine of inducement is distinct from that of inequitable conduct, commentators have already begun to recognize the applicability of willful blindness to inequitable conduct. $^{84}$

Specifically, willful blindness allows for a finding of culpable knowledge if the accused party believes that there is a high probability that a fact exists and takes deliberate actions to avoid learning of the fact. ${ }^{85}$ Applying this mechanism, courts may be able to establish the elements of the Therasense "specific intent" test, knowledge of the relevant information and knowledge of its materiality, even in the absence of the high standard Therasense seems to require.

This suggests that despite the majority's attempt to limit the intent element of inequitable conduct through formal rules, judges will largely be free to apply their own normative perspectives, either because they consider any dispute to largely involve factual questions (as the dissent apparently did) or through the potential invocation of the concept of willful blindness.

Accordingly, Therasense might produce the rather perverse result of encouraging or even requiring patent agents and attorneys to engage in riskier behavior, while at the same time failing to produce the doctrinal prophylaxis necessary to immunize the newly permitted conduct from the vagaries of a trial judge's equitable discretion. If so, patent practice post-Therasense might hold many unpleasant surprises for patent practitioners.

\section{Will Therasense Solve the Problem of Applicant Overdisclosure?}

Far and away the biggest concern we heard from patent practitioners about the current law of inequitable conduct is that pre-Therasense inequitable conduct doctrine required that patent applicants make an expensive disclosure of art that, in their mind, would not be important to a reasonable examiner in deciding patentability. ${ }^{86}$ That disclosure occurs mostly in the context of information disclosure statement (IDS) practice, the aspect of patent prosecution that involves the use of a standardized document to disclose information such as lists of references, and sometimes references themselves, to the patent office. Thus the

${ }^{84}$ See Kevin E. Noonan, Global-Tech Appliances, Inc. v. SEB S.A., PATENT Docs (May 31, 2011), http://www.patentdocs.org/2011/06/global-techappliances-inc-v-seb-sa-2011.html (noting the potential applicability of the concept of willful blindness to inequitable conduct).

${ }^{85}$ Global-Tech, 131 S. Ct. at 2070.

86 This concern was also one raised repeatedly by many of the comments we received in response to an earlier draft of this Article. 
disclosure concern sometimes goes by the label "IDS flooding," or the "overdisclosure problem."

The idea of an overdisclosure problem is commonly based on a widely held belief that the harsh consequences, both to the patent attorney personally as well as for the client, of a potential finding of inequitable conduct force applicants to disclose every reference that has even the slightest relationship to the invention or patent application, including references that a reasonable examiner would not consider important in deciding whether to let the claims of an application issue as a patent. ${ }^{87}$ This putative behavior ${ }^{88}$ overdisclosing out of fear of inequitable conduct law-presents a potential concern for patent quality, a concern that the court sought to address by its ruling in Therasense. The concern is that patent examiners faced with an information dump comprising large numbers of irrelevant or marginally relevant patents will have a costly time separating the wheat from the chaff. Information dumping, then, could result in the straining of concededly limited patent office resources and the burying of patentability-important information, thereby producing lower quality patents and perhaps causing examiners to ignore applicant-submitted art altogether. ${ }^{89}$

The concern that pre-Therasense inequitable conduct doctrine required patent applicants to overdisclose was particularly highlighted in the opinion for the court. ${ }^{90}$ In fact, it is arguably the claim the court found most dispositive to the holding it announced in Therasense. ${ }^{91}$ As noted earlier, the Therasense majority responded to the bar's plea for assistance by holding that in the

${ }^{87}$ See Cotropia, supra note 22 , at $770-71$. We recognize that pre-Therasense law did not require the disclosure references that a reasonable examiner would not consider important in deciding whether to let the claims of an application issue as a patent. We assume that patent practitioners - by virtue of being versed in patent law - also know this. Rather, the claim of the overdisclosure problem highlights a concern on the part of patent applicants that they needed to be more cautious than the law required in anticipation of the possibility of an unenforceability ruling in litigation.

${ }^{88}$ We characterize this as "putative" behavior for three reasons. First, while we have heard from some practitioners that they do this in certain circumstances, there is little empirical evidence concerning the extent of this practice in real life. Second, in briefing before the Federal Circuit, the patent bar and those who seek patents pressed the claim that this is common practice. Third, as we discuss later in this part, the notion that this practice is caused by pre-Therasense inequitable conduct law is not likely to provide a full explanation for why it occurs.

${ }^{89}$ See Cotropia et al., supra note 22 (empirically analyzing this phenomenon).

90 The court's opinion shows that the claim was convincingly pressed by amici. Therasense, Inc. v. Becton Dickinson \& Co., 649 F.3d 1276, 1289 (Fed. Cir. 2011) (citing the briefing of the United States and the Biotechnology Industry Organization as raising this specter of overdisclosure).

91 Id. at 1289-90 (recognizing the issue as important to and supportive of the court's modification of the inequitable conduct doctrine). 
absence of affirmative egregious misconduct, patent applicants only need to disclose art that is "but for" material to patentability, viz. if an applicant fails to disclose prior art during the prosecution, "that prior art is but-for material if the PTO would not have allowed a claim had it been aware of the undisclosed prior art." The purpose of this change in the law is to reduce the range of information that a patent applicant is required to submit to the patent office. But will it really? In the analysis that follows, we suggest that the answer to the question may be "no," and we explain why.

In broad strokes, the answer has to do with (1) the nature of the change in the law and the patent law itself, and (2) the benefits to patent applicants of, in at least some cases, making massive indiscriminant disclosures of information.

i. The nature of the change in the law and the patent law itself

Nothing in Therasense insulates an applicant who fails to disclose a key reference from a finding of inequitable conduct. At most, the rules in Therasense limit the category of potentially material information to the "but for" category. But given the dire consequences of a finding of inequitable conduct, there remains a strong incentive for applicants to continue to disclose everything they come across that might be relevant out of a fear that the art might be "but for" art.

Patent law is too complex, unpredictable, and policy driven for applicants to know with certainty whether information is "but for" art. To determine patent validity, claims have to be construed - a legal process the outcome of which is not always predictable. Only after claims are construed can one even begin to compare the claimed invention to the prior art or the scope of the disclosure. Without an authoritative claim construction, there will be considerable disagreement over whether information is "but for" information.

The situation is only slightly improved once an authoritative claim construction is established. ${ }^{93}$ The legal rules around obviousness, patentable subject matter, description and enablement, and even novelty are not so legally determinant that it is easy to predict what the patent office would do in light of particular pieces of information. Reasonable people will thus still often disagree about whether certain information might invalidate a patent claim. Accordingly, even if an applicant were to pay the

${ }^{92}$ Id. at 1291.

${ }^{93}$ Not the least reason being that the claim construction itself will often need to be interpreted. 
cost of closely considering whether a prior art reference discloses "but for" information, in cases that are at all close there is always a probability that a court might later reach a different conclusion. Arguably, the path to safety is to go ahead and disclose the art in the first instance.

Moreover, there is always the possibility that even if the applicant properly assesses the "but for" quality of a particular prior art reference at the time it is prosecuting the patent application, the law could change by the time the patent gets litigated. A first response to this concern is "so what?": if the art is not material at the time of prosecution, it's just not material and the applicant should have no worries. In addition, in all but the most marginal of cases it would seem impossible to conclude that an applicant had intent to deceive. Assuming the technical correctness of this response, however, its flaw is essentially that it is too technical a response. It is possible that a patentee might have a hard time showing the correctness of a decision made 10 or 15 years earlier. The passage of time, the arguments available to make claims as to what the law "was," and the talent vel non of litigation counsel are all risks patent practitioners face. Arguably, the path to safety is (again) to go ahead and disclose the art in the first instance.

Finally, in addition to these theoretically developed concerns, we would be remiss in not emphasizing the empirical information we have gathered from actual patent practitioners. In response to an earlier draft of this Article, we received many comments from patent practitioners. In the comments that addressed this point, the overwhelming indication was that practitioners have no intention of changing their IDS practices and will continue to disclose large numbers of references when they feel it to be appropriate.

\section{ii. The benefits to patent applicants of current IDS} practice

It is common ground that patent applicants sometimes make large disclosures of information in the course of prosecuting patent applications. ${ }^{94}$ However, the true extent to which it happens

${ }^{94}$ It might be more likely to happen in particular kinds of circumstances: for example, a patent applicant who is prosecuting multiple related patents may decide to disclose every prior art document that is cited in any one of the applications in all of the proceedings. Adding another layer, if any one of those patents is involved in litigation, the applicant may choose to cite to the patent office every prior art reference asserted by the accused infringer in its defenses. Yet another layer is added if there are related foreign patent applications. The net result is patent applications containing hundreds of citations spanning multiple pages. 
is an empirical question, about which there is surprisingly little empirical evidence ${ }^{95}$ given the court's heavy reliance on the claim. ${ }^{96}$ The majority adopted the position that the problem was significant, ${ }^{97}$ an empirical guess that was put into sharp relief by the dissent and by the patent office's apparent view (and perhaps equally a guess) that the concern was either not as significant as the majority claimed or at least manageable. ${ }^{98}$

A comprehensive empirical investigation of the claim of IDS overdisclosure would be nice to have. But even without knowing how often massive disclosures happen, we think they should be expected in some cases. Patent applicants have economic incentives to sometimes make large IDS disclosures that go beyond a fear of inequitable conduct, including disclosures of art that would not be important to a reasonable examiner in deciding patentability.

The practice of overdisclosing likely has the benefit to the applicant of being much less expensive than examining all of the known potentially relevant references and sorting that genus into species that would have been important to a reasonable examiner (or those that would be "but for" references) and those that would not have been important. By disclosing everything under the sun, a patent applicant can get protection from inequitable conduct and avoid a costly analysis of the significance of the various pieces of information that it submits. Moreover, applicants get a further benefit from this practice because it works to shift to the patent office more of the cost of determining what, if anything, in the disclosed information is important to patentability. As we noted earlier, it is common ground that patent office resources are already strained, and strategies that make the cost of patent examination higher for the patent office can be expected to

\footnotetext{
95 The only empirical research on this issue of which we are aware is Dennis Crouch's analysis of applicant disclosure rates from 2005-2010. Dennis Crouch, Cutting Back: Average Number of References Cited Per Patent, PATENTLY-O, http://www.patentlyo.com/patent/2010/07/my-entry.html (July 13, 2010, 10:23 AM) (indicating an upward trend from 2005-2009, followed by a drop-off in 2010). Furthermore, additional research by Professor Crouch suggests that the bulk of these references were submitted in only a small percentage of applications. Dennis Crouch, References Cited, PATENTLY-O, http://www.patentlyo.com/patent/2009/02/references-cite.html (Feb. 19, 2009, 12:34 PM) (noting that applicants submit over 200 references in just $2 \%$ of cases).

${ }^{96}$ Therasense, 649 F.3d at 1289.

${ }^{97}$ The majority used two examples to highlight this issue: a patent involving the submission of nine hundred references (cited by the Brief for the United States as Amicus Curiae) and one involving the submission of eighteen pages of cited references (cited by the Brief of the Biotechnology Industry Organization as Amicus Curiae). Id.

${ }^{98}$ Therasense, 649 F.3d at 1305 (Bryson, J., dissenting).
} 
encourage marginally poorer examination, lower quality patents, and the spurious rejection of deserving applications.

In fact, some empirical studies suggest this has been exactly the impact of large disclosures. ${ }^{99}$ Patent examiners may not pay attention to them, preferring instead to perform and rely on just their own search rather than taking on a costly analysis into the significance of the various pieces of information submitted by the applicant - many of which, according to applicants and Cotropia et. al., are not the sorts of things examiners will find important anyway. 100

A second reason why patent applicants might make large disclosures is that it works to create the impression, on paper at least, that the information submitted has been examined in connection with the patent that ultimately issues from the application. The perception, and probably the reality to at least a modest extent, is that the more art considered by the examiner, the stronger the patent (due to a presumption of administrative correctness). Thus, getting lots of information listed in the file history is helpful to a patent applicant because it makes the patent marginally more valuable. ${ }^{101}$

Accordingly, an analysis of the potential impact of Therasense on practitioner concerns suggests that there are reasons to believe that the opinion will not substantially address the concerns that patent practitioners generally made and pressed in

99 See Cotropia et al., supra note 22, at 25-27 (assessing the use by patent examiners of applicant-disclosed references and finding that examiners "regularly ignore...information submitted by the applicants themselves").

${ }^{100} \mathrm{Id}$. at $22-27$.

101 We acknowledge that the overdisclosure problem is a viable concern, although one for which further empirical support would be beneficial. Even assuming there is a significant concern, however, we are unpersuaded at the present time that Therasense provides a solution. Thus, while the primary purpose of this Article is to analyze the court's opinion, we nevertheless take a moment to suggest a modest proposal in connection with this issue. Based on our experience and our interaction with practitioners, it appears that the sorts of documents most involved in IDS flooding could be U.S. patents and U.S. patent applications. One possible solution to the overdisclosure problem would be to adopt a general presumption that all U.S. patents and patent applications are before the patent examiner, and unless extraordinary (and perhaps particular) circumstances exist, the failure to disclose such documents cannot be the basis for a finding of inequitable conduct. A rule such as this has the merit of being a fairly bright line rule; it targets what we believe may be the most pernicious class of documents involved in IDS flooding; and it allows private parties to shift resources toward a focus on nonpatent prior art that the patent office and competitors without the patent applicant's disclosures may be unlikely to discover. Obviously, this footnote provides only the roughest of sketches, and the idea presented here should receive further examination and analysis before it is taken too seriously. 
connection with the en banc case. It may be reasonable to expect a similar number of successful claims of patent acquisition misconduct, and patent applicants' incentive to overdisclose may not be at all affected by the court's holding.

\section{E. What Does It All Mean?}

The short answer is that it depends. And the more complete answer lies ultimately in the marginal impact of the decision on the issues we raise in Parts II. A, B, C, and D. There is obviously some amount of tension between the interpretation that if Therasense has the impact the majority hopes for then patent quality will suffer and the interpretation that Therasense may not have the impact that the majority hopes for because of its impact on patent acquisition misconduct doctrines and its lack of impact on the reasons why patent applicants sometimes overdisclose information. The important point of the analysis in this Part is that these two analytical interpretations are not logical opposites, nor is their relationship a simple, inverse one. It is not, we suggest, the case that if there is no reduction in overdisclosure and no reduction in findings of patent acquisition misconduct, then Therasense will have no impact on patent quality, no impact on the incentive structure of the patent system, and no impact on patent practitioners. Below, we approach the explanation from two polar perspectives, first considering the consequences if the court is entirely right, and then turning to examine what it means if the court is entirely wrong-recognizing that the likely answer actually lies somewhere between the two poles.

If the court is entirely right and its opinion has perfected a rent shift from the public and the patent office to the patent bar and those who seek patents, then one might expect an alleviation of some practitioner concerns about the risks and consequences of inequitable conduct. The expected tradeoffs - again, assuming one does not believe that private resources now retained by patent applicants were not before Therasense mostly wasted-are several. Patent examination will be marginally less efficient in the sense that information useful to it will no longer be provided by the cheapest cost providers of the information. Some information will instead come from more expensive cost providers or will not be provided to the patent creation process at all. Patent examination might thus be expected to be more poorly performed. It follows that patent quality might marginally decrease from spurious allowances. In addition, the incentive structure of the patent system may additionally be damaged by the spurious rejection of deserving applications. Moreover, as we have demonstrated, the burden of litigation to the patent system could well be enhanced by 
the court's decision in Therasense.

On the other hand, even if the majority is entirely wrong and the court's efforts to encourage practitioners to disclose much less and to insulate practitioners from claims of inequitable conduct fail, all of the above concerns are unfortunately not completely reversed. The pre-Therasense status quo does not necessarily return.

To begin with, as we have demonstrated, the new patent acquisition misconduct doctrines seem very difficult to predict. At a minimum, substantial litigation will be required to establish a new doctrinal equilibrium. Thus, the new misconduct doctrines could still substantially aggravate the systemic cost of patent litigation. There is an additional concern that by defining a new line for acceptable behavior, the court may be encouraging, and, in combination with general rules of professional ethics, perhaps requiring patent attorneys and agents to engage in riskier behavior. This incentive will be perverse in view of misconduct doctrine that fails to have the prophylactic benefits the bar seems currently to expect from Therasense.

Finally, while the court's efforts to limit the information patentees disclose to the patent office in IDSs may fail, it is possible that the court's decision may be still be felt on that point. Unfortunately, it is possible that the court's opinion may be used to justify the nondisclosure of information about which the patent office and potential competitors are highly unlikely to learn. To be clear, we believe that patent applicants - or their agents - as a group do not want to engage in misconduct. But as we have shown, patent applicants may be strongly encouraged, or even required, to make nondisclosure decisions because of the court's new materiality standard. In addition, taking the "but for" standard in view of the vagaries of the patent law, it is probably indisputable that patent practitioners will have more "moral leeway" after Therasense in deciding not to disclose. Thus, it is possible that one of the enduring legacies of Therasense is that patent practitioners will struggle even more with competing duties and powers: they may face a stronger professional duty to come up with rationales for why information is not "but for" material and thus need not be disclosed, while at the same time, they have been given greater discretion to unilaterally determine the statutory requirements for patentability. Keeping in mind that patents are very rarely litigated, which might already present something of a moral hazard, these competing principles could present serious problems for practitioners and the patent system. Moreover, one might expect that the incentives are at their worst when there is a perception of a low likelihood of discovery, namely when the disclosure decisions involve art or information that no one else is likely to find. 
Therasense might thus end up accentuating the system's negative aspects while providing little to no positive systemic benefits.

\section{A Glimpse of the New Federal Circuit?}

The Federal Circuit has recently seen many judges of long tenure move to senior status or leave the court entirely, and the last few years have seen the appointment of several new circuit judges. ${ }^{102}$ There is a general expectation that with such substantial change in active membership, the complexion of the court is likely to change. Therasense provides, perhaps, our first glimpse at the new Federal Circuit. In particular, we note the important role that the three newest appointees to the court played in the outcome: both Judges Moore and Reyna joined with the majority opinion, and Judge O'Malley concurred with its result. With the court so closely divided on the issue of inequitable conduct, the addition of these judges to the mix may have produced a completely different result than would have been the case even a year ago.

As we have throughout this Article, we raise issues specifically implicated by the majority's opinion in the Therasense case. It is especially important to keep this limitation in mind in this Part as we base our analysis on the anecdote of a single opinion, and, at that, not even one signed by all of the judges, ${ }^{103}$ to make some observations about what the new generation of the Federal Circuit might look like.

\section{An Ex Post, not an Ex Ante Patent System}

For years, Congress, the Supreme Court, and the Federal Circuit have developed patent jurisprudence based on the conception that the patent system is a property rights-based system. The policies implicated by the concept include an emphasis on voluntary transactions around patent rights, with litigation being the exception. In short, the patent system is supposed to promote

${ }^{102}$ In the four years preceding Therasense, four judges (Judges Haldane Mayer, Raymond Clevenger, III, Alvin Schall and Paul Michel) (roughly a third of the court) have taken senior status or left the court entirely, while three new judges (Judges Kimberly Moore, Kathleen O'Malley, and Jimmie Reyna) have been appointed. Since Therasense was decided, an additional judge (Judge Arthur Gajarsa) has taken senior status and Congress has appointed one more new judge (Judge Evan Wallach).

${ }^{103}$ To this point, it should be clear that while we paint with a broad brush-as is appropriate in talking about an opinion for the court - it must be acknowledged that at least four of the court's judges specifically rejected the majority's decision, and even if that were not true, our observations cannot be applied to any of the court's judges individually. 
the allocation of resources through markets, not through federal district court judges. Crucial to this concept is the ability of market participants to transact ex ante-before litigation. As the Supreme Court bluntly put it almost fifty years ago, "[t]o await litigation is - for all practical purposes - to debilitate the patent system."104

The Therasense decision suggests the possibility that the new Federal Circuit might be willing to abandon these core principles in favor of a system that is, at least marginally, more of an ex post system - one where more transactions happen after (or through) litigation. In other words, Therasense may foreshadow a patent system in which litigation will become more important and ex ante negotiation, licensing, and contracting less so. This is possible because, as we have speculated in the previous Parts, the direction of the change in the law produced by Therasense is to make patents cheaper and easier to get. Moreover, it is probable that the patent office will be forced to determine patentability in view of even less information about whether the invention should be patented than the patent office utilized before Therasense. If this eventuality is realized, it suggests that patentees will own more patents that could be found invalid by a district court judge. In other words, the first real patent examination would occur at the patent infringement stage, not at the patent application stage. Logically, this could lead to greater ex ante uncertainty around patent rights and raise the cost of negotiation to the point that it is cheaper to negotiate using litigation. If so, the result may be more patent allocation decisions being made by federal district court judges rather than by private parties transacting in the marketplace. ${ }^{105}$

\section{A More Political Federal Circuit?}

The opinion for the majority in Therasense has the flavor of an announcement as opposed to a detailed analysis of the relevant public policy. And since it is an announcement that at least facially favors perhaps the court's most influential constituencies-the patent bar and those who seek patents - it raises the specter that the new Federal Circuit might be substantially more political than the old one.

From the majority's opinion, it seems evident that the patent bar and those who seek patents strongly desired the holding; the opinion contains several pages of citations to the concerns of the patent bar, which it clearly finds relevant-if not

\footnotetext{
${ }^{104}$ Graham v. John Deere of Kansas City, 383 U.S. 1, 18 (1966).

${ }^{105}$ This analysis leaves aside the concern that Therasense might in time spawn a cottage industry of patent acquisition misconduct litigation. If that also happens, it should be expected to push even further in the direction of an ex post system.
} 
determinative - to its decision to raise the standard for establishing inequitable conduct. ${ }^{106}$ The bar's actual concerns were, however, rather vague, essentially amounting to unsubstantiated empirical claims about the patent acquisition and patent litigation burdens of inequitable conduct. ${ }^{107}$ The litigation burden claim has become even more questionable since the Federal Circuit heard the case, and the patent office, the institution the bar claimed needed to be protected from the overdisclosure of information relating to the patentability of inventions, downplayed the concern in its own brief. ${ }^{108}$ In fact, the patent office asked not to be relieved of the information patent applicants were required to submit. ${ }^{109}$ It expressed the concern that it would be unable to perform quality patent examination unless it could get information from applicants beyond that which would be just "but for" patent defeating. ${ }^{110}$

Thus, it is somewhat discouraging that, other than some conclusory statements to the effect that the public will benefit from its decision (mostly, it appears, on the predictions that (1) less will be spent litigating inequitable conduct, and (2) patents will cost less to obtain), the majority opinion in Therasense offers almost no analysis of the issues involved from the perspective of the public. ${ }^{111}$ This stands in sharp contrast to the dissent, which provides a much deeper analysis of the policy issues implicated by the law of inequitable conduct and analyzes the issues with a focus on the public consequences of the decision. ${ }^{112}$

So perhaps, just perhaps, we are seeing a more political Federal Circuit emerging. Perhaps the old court is giving way to a new court that seeks to be more "in tune" with the constituencies affected by its decisions. In administrative law lingo, perhaps we are seeing the receding of a public interest Federal Circuit and the emergence of a public choice Federal Circuit.

\section{A Pro-Patentee Federal Circuit?}

Therasense seems to be a remarkably pro-patentee opinion, as distinguished, perhaps, from a pro-patent system opinion. The rationale for this interpretation has already been discussed in the earlier Parts of this Article. However, it is difficult to speculate about how generalizable a pro-patentee interpretation might be. It

${ }^{106}$ See Therasense, Inc. v. Becton Dickinson \& Co., 649 F.3d 1276, 1288-90 (Fed. Cir. 2011).

${ }^{107}$ Id. at 1288.

${ }^{108} I d$. at 1305-06 (Bryson, J., dissenting).

${ }^{109} \mathrm{Id}$.

${ }^{110} I d$.

${ }_{111}^{11}$ See, e.g., id.at 1290 (majority opinion).

${ }^{112} \mathrm{We}$ are not suggesting that the dissent is necessarily correct; only that its opinion contains substantially more rigorous analysis than the majority opinion. 
might easily be the case that this opinion is something of a one-off, and that the Federal Circuit is not at all moving in a pro-patentee direction. In addition, it must be noted that if our predictions in the preceding Parts turn out to be correct, the eventual result of Therasense might be perverse to the interest of patentees. They could actually be worse off in the future than they were before Therasense due to increased uncertainty about whether their patent rights are enforceable and, potentially, a diminished public opinion about the patent system.

\section{CONCLUSION}

The purpose of this brief Article has been to provide an early analysis of some of the most substantial law and policy concerns raised by the very recent en banc decision of the United States Court of Appeals for the Federal Circuit in the Therasense $v$. Becton Dickinson case. Using theoretical logic and policy analysis, we have identified substantial law and policy concerns that are raised by the court's decision but that were left largely unaddressed by the court's analysis. Our Article does not show that the "sky will fall" or that the court's opinion in Therasense will "destroy the patent system." To the contrary, we think the Article teaches that the impact of the Therasense decision can only be properly analyzed with an appreciation of the many and complex interactions involved in the patent creation and patent litigation environments.

On the court's side of the ledger can be placed the benefits it predicts for its approach; namely, that it is might be the case that Therasense will make patents cheaper to obtain and cheaper to enforce. This Article's contribution is to begin a discussion of what may be counted on the other side of the ledger. We identify a number of possible costs to the court's approach: inter alia, a higher cost in bringing information to bear on the patentability determination; a potential decrease in the quality of information brought to bear on the patentability determination; a potential increase in the number of low-quality patents; and the potential reputational and economic costs to the patent system of a misconduct doctrine that might be more complex and dangerous to patent applicants and the patent system than the one it replaced.

From that perspective, our analysis suggests that the opinion for the court might be too optimistic in its expectation that a simple and straight line can be drawn from making patents cheaper to obtain and cheaper to enforce to an increased public, and for that matter patentee, benefit. That said, it will take time and additional analysis to determine if, at the end of the day, the court's efforts to reduce the risk of inequitable conduct to patent applicants will provide a benefit to the patent system that outweighs the costs. 